\title{
Erratum to: Parents atteints de cancer : comment en parler aux enfants?
}

\section{Erratum to: Parents with Cancer: How to Talk to Children about It?}

Erratum to: Psycho-Oncol. DOI 10.3166/pson-2018-0016

En page 38, volume 12, numéro 1, mars 2018, concernant le $4^{\mathrm{e}}$ auteur dans la liste des auteurs et dans les affiliations, il faut lire :

M. Reich 